\title{
Differentiation Between $E$. colis Strains Causing Diarrhea in Broiler Chicken by Using Multiplex PCR
}

\author{
Mona A. Ahmed, Fatma M. Youssef and A. G. Abdel Rahman \\ Animal Health Research Institute, Ismailia and Alarish Branch, \\ Ministry of Agriculture, Egypt.
}

\begin{abstract}
7 HIS TRIAL was to investigate the outbreak of acute diarrhea in acute diarrhea in poultry birds at Ismailia, and North Sinai for North Sinai for detection and characterization of shiga toxin Escherichia coli (STEC). Two hundred samples from natural diseased and emergency slaughtered broiler chicks were collected from poultry farms in Ismailia and North Sinai. All cases were subjected to postmortem, bacteriological examination, hematological and biochemical analysis. Escherichia coli (E. coli) was isolated and identified from cloacal swabs, intestinal contents, heart blood and liver of poultry birds that died due to acute diarrhea. Phenotypic characterization was done by standard bacteriological and biochemical techniques. All the isolates were serotyped based on their somatic antigens. Virulence genes (stx1, stx2, eaeA and $h l y A)$ were detected by multiplex PCR assay.A total of $20 \mathrm{E}$. coli isolates were obtained, of which O6(6), O111 (2), O55 (3), O114(2), O15(3), O125(2), and untyped (2). Out of 20 serotype, O6 carried one virulence gene of stx 1 and 0125 carried one virulence gene of stx 2 . The other all serotype didn't carried virulence gene. The biochemical analysis of blood showed increase in AST and ALT and a significant change inprotein. Hypoalbuminemia, was observed and increase of serum uric acid, creatinine and phosphate as well as decrease in level of potassium,calcium and sodium. Blood examination revealed a significant decrease in RBcs count, hemoglobin $(\mathrm{Hb})$ concentration and packed cell volume (PCV) in the affected birds indicate anemia of microcytic hypochromic.It could be concluded thatthe isolated bacterial pathogens play an important role in causing diseases in poultry and human consumer due to presence of toxin and losses in poultry farms at Ismailia and North Sinai.
\end{abstract}

Keywords: Escherichia coli, broiler chicken, multiplex PCR, Virulence genes.

Colibacillosis is one of the most important diseases threatening the poultry industry (Ibrahim, 1998, Ewers et al., 2005 and Ayoub, 2007). Colibacillosis in chickens refers to any local or systemic infection caused entirely or partly by $E$. coli strains (Barnes et al., 2003). Escherichia coli, strains causing systemic disease in poultry (avian colibacillosis) are termed avian pathogenic E. coli (APEC) (Ewers et al., 2005). Traditionally, it was mostly associated with losses in broilers but, recently the incidence of the disease in layer hens has been substantially increased in many European countries (Zanella et al., 2000, Vanderkerchove et al., 2004 and Jordan et al., 2005). 
Escherichia coli, has been associated with a variety of diseases in poultry such as pericarditis, perihepatitis, airsacculitis, peritonitis, salpingitis, panophthalmitis, omphalitis, cellulites, colispticemia, coligranuloma and swollen-head syndrome (Saif et al., 2003).

Strains of $E$. coli predominate among the aerobic commensal flora in the gut of humans and animals. These bacteria are widespread and present wherever there is fecal contamination, causing pollution of water sources, drinking water and food. The species encompasses a variety of strains, which may be purely commensal or possess combinations of pathogenic mechanisms that enable them to cause disease in man and other animals (Greenwood et al., 2002). The avian intestinal tract harbors both potentially pathogenic and commensal E. coli strains and infections generally arise from inhalation of contaminated dust particles in poultry houses (Dziva, 2010).The versatility of $E$. coli is due to the fact that different strains have horizontallyacquired different virulence genes (Salyers and Whitt, 2002).

Even though, molecular methods for identifying specificvirulence genes are available, serotyping remains a useful toolfor epidemiologic studies. Numerous surveys have been made inmany parts of the world to determine serotypes most frequently associated with disease in poultry caused by E.coli (Sharada et al., 2001, Rosario et al., 2004 and Thangapandian et al., 2006). Enterotoxigenic Escherichia coli (ETEC) serotype O6 and O111 was the most common ETEC serotype identified during outbreaks occurring in the United States (Dalton et al., 1999). Shiga toxin-producing Escherichia coli (STEC) are major food-borne pathogens associated with gastroenteritis and sometimes fatal haemolyticuraemic syndrome complication to human consumer (Dalton et al., 1999, Beatty et al., 2004 and Ojo et al., 2010).

Hematological alterations were recorded the severity of infection of E. coli, a significant decrease in RBcs count, $\mathrm{Hb}$ concentration and PCV in the affected birds indicate anemia of microcytichypochromic (Mona et al., 2012). Moreover, The biochemical analysis recorded increase in AST and ALT and a significant change inprotein. Hypoalbuminemia, was observed, increase of serum urea, creatinine (Mona et al., 2012).

Aim of the work: The specific objective of this study was planned as the following: isolation and identification of E.coli from different organsof broiler chicken as well as from cloacal swab, serotyping of isolated E. coli, detection of virulence genes of isolated E.coli by using of polymerase chain reaction (PCR) and determined the effect of these pathogenic organisms on blood indices with liver and kidney functions. 


\section{Material and Methods}

\section{Collection of samples}

An outbreak of diarrheal disease in farms of broiler chickens at Ismailia and North Sinai in 2012 was attended. A total of 200 birds were collected (50emergency slaughter and 150 diseased). These birds were brought to the microbiology and clinical pathology labs in Ismailia and Alarish. During postmortem examination, cloacal swabs, intestinal contents, heart blood, kidney and pieces of liver were collected aseptically for isolation and identification of causative agents.

\section{Bacteriological screening of clinical specimens}

The clinical samples (heart blood, liver, kidney, cloacal swab, intestinal contents) were immediately inoculated on 10 per cent sheep blood agar and MacConkey's agar (HiMedia, Mumbai, India) plates and incubated at $37^{\circ} \mathrm{C}$ for 18-24 h. Pure and a single population of bacterial colonies were recorded from all samples. Five randomly selected colonies from MacConkey's agar and 10 per cent sheep blood agar plates were picked up and subcultured on eosin methylene blue (EMB) agar (HiMedia, Mumbai, India) plates to observe the characteristic metallic sheen of $E$. coli. The well separated pure colonies were picked up on nutrient agar slants as pure culture and subjected for standard morphological and biochemical tests (Quinn, et al., 1994).

Serotyping of E. coli

The 20 E. coli isolates were serotyped based on their somatic $(\mathrm{O})$ antigens at Animal health research institute, Dokki, Egypt.

Preparation of E. coli DNA for PCR assay

Boiling method (Bansal, 1996). Bacterial pellets were washed once with $1 \mathrm{ml}$ phosphate buffered saline (PBS), $\mathrm{pH} 7.4$, resuspended in a same volume of cold water and incubated in a boiling water bath for $10 \mathrm{~min}$. The clear supernatants obtained after a 5 min centrifugation at $12000 \mathrm{~g}$ were used for PCR reaction.

\section{Detection of virulence genes by multiplex PCR}

A multiplex PCR was carried out using 4 sets of oligonucleotide primers for stx 1, stx 2, eaeA and hlyA genes (Table 1). The PCR protocol was followed as per the method described by Paton and Paton1 (1998) with some modifications. In brief, the multiplex PCR mixture of $25.0 \mu \mathrm{l}$ contained 1X PCR buffer, $1.5 \mathrm{mM}$ of $\mathrm{MgCl} 2$, each primer within the 4 primer sets at a concentration of $40 \mathrm{nM}, 200$ $\mu \mathrm{M}$ each of dNTPs, $1.0 \mathrm{U}$ of TaqDNA polymerase and $2.0 \mu \mathrm{l}$ of template DNA. The PCR reaction was performed in a thermal cycler (Thermo Electron, Germany) using the following standard cycling procedure: an initial denaturation at $95^{\circ} \mathrm{C}$ for $5 \mathrm{~min}$, followed by 30 cycles of denaturation at $94^{\circ} \mathrm{C}$ for $45 \mathrm{sec}$, primer annealing at $59^{\circ} \mathrm{C}$ for $45 \mathrm{sec}$ and extension at $72^{\circ} \mathrm{C}$ for $1 \mathrm{~min}$ and a final extension at $72^{\circ} \mathrm{C}$ for $6 \mathrm{~min}$. 
Amplified products were separated by agarose gel (2\% agarose in $1 \mathrm{X}$ Trisborate-EDTA buffer) electrophoresis at $5 \mathrm{v} / \mathrm{cm}$ for $2 \mathrm{hr}$ and stained with ethidium bromide $(0.5 \mu \mathrm{g} / \mathrm{ml}) 14$. Standard molecular size marker (100 bp DNA ladder) was included in each gel. DNA fragments were observed by ultraviolet transilluminator and photographed in a gel documentation system (Alpha Imager, Germany). Amplified products were separated by agarose gel (2\% agarose in $1 \mathrm{X}$ Tris-borate-EDTA buffer) electrophoresis at $5 \mathrm{v} / \mathrm{cm}$ for $2 \mathrm{hr}$ and stained with ethidium bromide $(0.5 \mu \mathrm{g} / \mathrm{ml}) 14$. Standard molecular size marker (100 bp DNA ladder) was included in each gel. DNA fragments were observed by ultraviolet transilluminator and photographed in a gel documentation system (Alpha Imager, Germany).

The PCR was performed three times to ensure the repeatability of the technique and to make sure that isolates were correctly assigned to respective patterns.

TABLE 1. Oligonucleotide primers used in multiplex PCR reaction.

\begin{tabular}{|c|c|c|}
\hline SI No & Primers & Primer sequences \\
\hline $\begin{array}{l}3 \\
4\end{array}$ & $\begin{array}{l}\operatorname{stx}_{1} \mathrm{~F} \\
\operatorname{stx}_{1} \mathrm{R} \\
\operatorname{stx}_{2} \mathrm{~F} \\
\operatorname{stx}_{2} \mathrm{R} \\
\text { eaeAF } \\
\text { eaeAR } \\
\text { ehxAF } \\
\text { ehxAR }\end{array}$ & 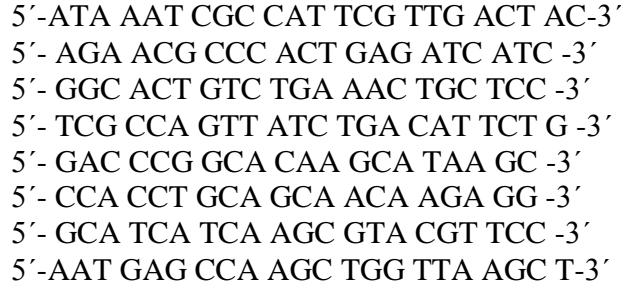 \\
\hline
\end{tabular}

Source: Paton and Paton1 (1998)

F: Forward

R: Reverse

\section{Hemogram}

Blood samples were collected from diseased and emergency slaughter birds. Erythrocytic count and total leucocytic count were performed using the improved Neuoberhaemocytometer with and Natt and Herrick solution as diluting fluid according to the method described by Natt and Herrick (1952). Determination of hemoglobin was performed as described by Van Kempen and Zijlstra (1961). The packed cell volume (PCV) was estimated according to Coles (1986). Blood films stained with Giemsa stain were prepared for the determination of differential leucocytic count (Jain, 2000).

\section{Serum biochemical parameters}

Serum samples were collected from diseased and emergency slaughter birds. Aspartate and alanine aminotransferase (AST and ALT) activities were determined calorimetrically according to Reitman and Frankel (1957). Total proteins and Albumin were determined according to Doumas and Biggs (1972).

Egypt. J. Vet. Sci. Vol. 44 (2013) 
Serum creatinine was determined according to Henry (1979) and uric acid (Caraway, 1963). Serum calcium was according to Sarkar and Chanhan (1967), phosphorous was measured according to Goodwin, (1970), sodium and potassium were determined by flame photometer.

\section{Statistical analysis}

The data were statistically analyzed according to Snedecor and Cochran, (1982).

\section{Results}

\section{Epidemiological details and post mortem observations}

Out of 200 birds, 50 were emergency slaughter and 20 died from 150 diseased broilers within one week time with an overall mortality and case fatality rate of 10 per cent (20/200). Prior to death, the affected birds were anorexic and emaciated, dull and depressed with ruffled feathers and showed progressive somnolence with closed eyes. Majority of the birds were shivering and huddled near the source of heat. Clinically ill birds showed profuse watery diarrhea and severe dehydration. On post- mortem, besides the generalized septicemic lesions, severe lesions of enteritis accompanied with focal necrotic lesions in the mucosa of the small intestine were prominent in majority of the cases. Spleens and livers were swollen and congested with hemorrhagic or necrotic foci.

\section{Bacterial isolation and characterization}

The bacteriological examination of heart blood, liver, kidney, cloacal swab and intestinal contents revealed the presence of Gram-negative bacilli. In biochemical tests, the isolates were identified as E. coli. Investigation of 250 samples collectedfrom emergency slaughter birds (200 organs) and cloacal swabs (50) revealed that $E$. coli isolates was recovered from 160 samples with overall prevalence $64 \%$.Concerning fresh heart blood samples, 20 out of 50samples of examined fresh heart blood were $E$. coli positive with an incidence of $40 \%$. The examined of 50 liver samples, $E$. coli were positive in 40 with a percentage of $90 \%$. Moreover, 50 kidney samples collected from emergency slaughter broilers were investigated. Out of 50 examined kidney samples, 30 were E. coli positive with a prevalence of $60 \%$. Concerning examination of small intestine of emergency slaughter broilers, 40 out of 50 samples were positive for $E$. coli with a prevalence of $80 \%$. Finally, isolation of $E$. coli from cloacal swabs of diseased broiler. Thirty out from 50 samples of cloacal swabs revealed E.coli isolation with prevalence of $60 \%$. Results of serological tests of 20 isolates from organs and cloacal swabs were illustrated in Table 2. 
TABLE 2. Serotyping of $E$. coli isolates recovered from examined samples.

\begin{tabular}{|c|l|l|}
\hline No. of isolate & Source of isolate & Serotype \\
\hline 1 & Liver & Un typed \\
\hline 2 & Intestine & O125 \\
\hline 3 & Cloaca & O111 \\
\hline 4 & Cloaca & O6 \\
\hline 5 & Cloaca & O55 \\
\hline 6 & heart & O114 \\
\hline 7 & liver & O15 \\
\hline 8 & intestine & O111 \\
\hline 9 & intestine & O6 \\
\hline 10 & Heart & O55 \\
\hline 11 & intestine & O15 \\
\hline 12 & heart & O125 \\
\hline 13 & liver & O15 \\
\hline 14 & Cloaca & O6 \\
\hline 15 & liver & O6 \\
\hline 16 & heart & O55 \\
\hline 17 & intestine & untyped \\
\hline 18 & heart & O6 \\
\hline 19 & liver & O114 \\
\hline 20 & kidney & \\
\hline
\end{tabular}

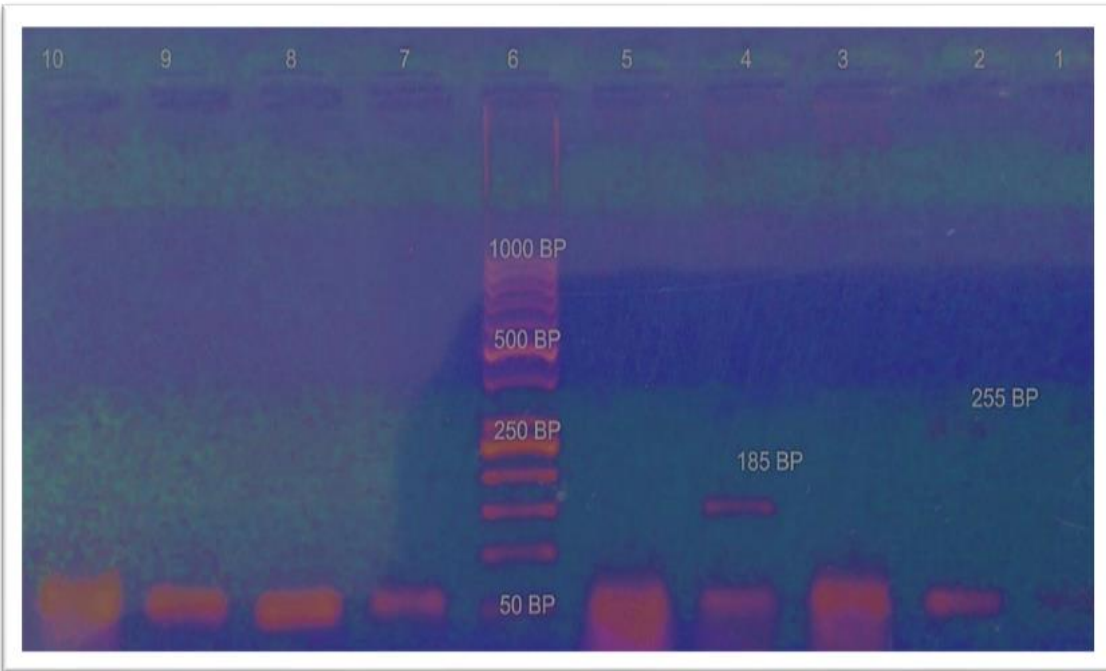

Fig. 1. Agarose gel electrophoresis of $S t x 1, S t x 2$ and intim in genes from randomly selected $E$. coli (9 isolates). 6, 100 bplambda marker, Positive amplifications were presented as following, lane 2 , Stx2gene $(255 \mathrm{bp})(0125)$ isolated from intestine. Lane 4, Stxlgene (185bp)(O6) isolated from cloaca.

Egypt. J. Vet. Sci. Vol. 44 (2013) 
Multiplex PCR for virulence genes

Multiplex PCR assay yielded amplified products of $\sim 180 \mathrm{bp}, \sim 255 \mathrm{bp}, \sim 384 \mathrm{bp}$ and $\sim 534$ bp specific for stx 1, stx 2, eaeA and hlyA genes, respectively (Fig.1). Out of 20 isolates, O6 carried one virulence gene were detected as STEC carried only stx 1 , and 0125 carried one virulence gene of $s t x 2$.The other all serotype didn't carried virulence gene (Table 3). Table 4 revealed a significant decrease in RBcs count, hemoglobin ( $\mathrm{Hb}$ ) concentrations, $\mathrm{PCV}, \mathrm{MCV}, \mathrm{MCH}, \mathrm{McHc}$ also TLC such decrease was very highly significant on infection $(P<0.01)$. In Table 5 there is a significant increase in ALT and AST if compared with control group $P$ $<0.05$. Total protein and Albumin showed highly significant decrease if compared with control group. Table 6 revealed a significant increases inserum uric acid and creatinine and Phosphorous $(p<0.01)$. also there is a significant decrease in serum level sodium, potassium and calcium $(p<0.01)$.

TABLE 3. Virulence genes profile of $E$. coli strains isolated from poultry birds with diarrhea.

\begin{tabular}{|l|c|c|c|c|c|}
\hline Serogroup & No. of isolates & Stx1 & Stx2 & EaeA & HlyA \\
\hline O6 & 2 & $+v e$ & $-v e$ & $-v e$ & $-v e$ \\
\hline O111 & 1 & $+v e$ & $-v e$ & $-v e$ & $-v e$ \\
\hline O55 & 1 & $-v e$ & $-v e$ & $-v e$ & $-v e$ \\
\hline O114 & 1 & $-v e$ & $-v e$ & $-v e$ & $-v e$ \\
\hline O15 & 1 & $-v e$ & $-v e$ & $-v e$ & $-v e$ \\
\hline O125 & 1 & $-v e$ & $+v e$ & $-v e$ & $-v e$ \\
\hline Untyped & 2 & $-v e$ & $-v e$ & $-v e$ & $-v e$ \\
\hline Total & 9 & 1 & -- & -- & -- \\
\hline
\end{tabular}

TABLE 4. Some hematological parameters in healthy and diseased birds.

\begin{tabular}{|c|c|c|c|c|c|c|c|}
\hline Group & $\begin{array}{c}\mathbf{R B C s} \\
\left(\times \mathbf{1 0}^{\mathbf{6}} \boldsymbol{\mu l}\right)\end{array}$ & $\begin{array}{c}\mathbf{H b} \\
(\mathbf{g} / \mathbf{d l})\end{array}$ & $\begin{array}{c}\mathbf{P C V} \\
(\mathbf{\%})\end{array}$ & $\begin{array}{c}\mathbf{M C V} \\
(\mathbf{f l})\end{array}$ & $\begin{array}{c}\mathbf{M C H} \\
(\mathbf{p g})\end{array}$ & $\begin{array}{c}\mathbf{M C H C} \\
(\mathbf{g} / \mathbf{d l})\end{array}$ & $\begin{array}{c}\text { TLC } \\
\left(\times \mathbf{1 0}^{\mathbf{3}} \boldsymbol{\mu l}\right)\end{array}$ \\
\hline Control & $2.2 \pm 0.2$ & $8.4 \pm 0.2$ & $28.9 \pm 0.4$ & $131.4 \pm 11.8$ & $38.2 \pm 1.7$ & $29.1 \pm 1.1$ & $31.2 \pm 0.21$ \\
\hline Diseased & $1.7 \pm 0.6 *$ & $4.8 \pm 0.7 * *$ & $21.0 \pm 0.7 * *$ & $123.5 \pm 2.2 * *$ & $28.2 \pm 0.6 * *$ & $22.8 \pm 0.13 * * 20.2 \pm 0.13 * *$ \\
\hline
\end{tabular}

* Significant at $P<0.05 \quad * *$ highly significant at $P<0.01$.

TABLE 5. Changes of liver function tests in serum of chicken infested with $E$ coli.

\begin{tabular}{|l|c|c|c|c|}
\hline Group & $\begin{array}{c}\text { A S T } \\
(\text { IU/l) }\end{array}$ & $\begin{array}{c}\text { A L T } \\
(\text { IU/l) }\end{array}$ & $\begin{array}{c}\text { Total } \\
\text { proteins(g/dl) }\end{array}$ & $\begin{array}{c}\text { Albumin } \\
(\mathbf{g} / \mathbf{d l})\end{array}$ \\
\hline Control & $26.0 \pm 0.12$ & $15 \pm 0.24$ & $5.0 \pm 0.12$ & $2.50 \pm 0.04$ \\
\hline Diseased & $46 \pm 0.27 *$ & $28.8 \pm 0.66^{* *}$ & $3.6 \pm 0.70^{* *}$ & $1.00 \pm 0.70^{* *}$ \\
\hline
\end{tabular}

* Significant at $P<0.05$. ** highly significant at $P<0.01$. 
TABLE 6. Renal function in serum of chicken infested with $E$ coli.

\begin{tabular}{|c|c|c|c|c|c|c|}
\hline Group & $\begin{array}{c}\text { Uric acid } \\
\mathbf{m g} / \mathbf{d l}\end{array}$ & $\begin{array}{c}\text { Creatinine } \\
\mathbf{m g} / \mathbf{d l}\end{array}$ & $\begin{array}{c}\text { Calcium } \\
\mathbf{m g} / \mathbf{d l}\end{array}$ & $\begin{array}{c}\text { Phosphorous } \\
\mathbf{m g} / \mathbf{d l}\end{array}$ & $\begin{array}{c}\text { Sodium } \\
\mathbf{~ m E q} / \mathbf{l}\end{array}$ & $\begin{array}{c}\text { Potassium } \\
\mathbf{~ m E q} / \mathbf{l}\end{array}$ \\
\hline Control & $7.17 \pm 0.7$ & $1.5 \pm 0.6$ & $9.00 \pm 0.1$ & $6.19 \pm 0.23$ & $155 \pm 0.62$ & $8.0 \pm 0.13^{*}$ \\
\hline Diseased & $9.6 \pm 0.7 * *$ & $2.9 \pm 0.9 *$ & $6.1 \pm 0.12 * *$ & $8.1 \pm 0.80 * *$ & $122 \pm 0.1 *$ & $5.8 \pm 0.9 *$ \\
\hline
\end{tabular}

* Significant at $P<0.05$. ** highly significant at $P<0.01$.

\section{Discussion}

Poultry production plays an important role in providing valuable proteins, poverty alleviation and economic development. Despite great potential and opportunities, poultry production is threatened by many disease outbreaks, these diseases are the major constrains for developing the poultry industry (Ewers $e t$ al., 2005). During the investigation of the present outbreak of acute diarrhea in a poultry flock, the clinical symptoms and post-mortem study indicated the involvement of systemic infection by some enteric pathogens. Because of absence of group A rotavirus, Salmonella spp. or any other diarrhea causing parasites and isolation of pure hemorrhagic $E$. coli from heart blood as well as intestinal contents warranted for further investigation of virulence genes of $E$. coli isolates.

Typing of isolated bacteria, including $E$. coli could be achieved by phenotypic and/or genotypic protocols. The phenotypic characteristics method used for identification and characterization of E. coli are mainly the morphological and biochemical tests. Most of these techniques are not sufficiently sensitive to distinguish between different strains and they are affected by physiological factors (Fantasia et al., 1990). Therefore, serological protocol was established to differentiate $E$. coli isolates.

Regarding the morphological tests used for identification of $E$. coli, it was found that $E$. coli isolates are G-verods appeared as pink colonies when cultured on MacConkey media, green metallic colonies on EMB medium. Nearly similar results were noted by (McClure, 2000 and Ahmed, 2011).

In general, investigation of 250 samples collected from emergency slaughter birds and cloacal swabs revealed that $E$. coli isolates was recovered from 160 samples with overall prevalence 64\%. These results agreed with Ahmed (2011).

Concerning fresh heart blood samples, 20 out of 50 samples of examined fresh heart blood were E. coli positive with an incidence of $40 \%$. Nearly similar results were recorded by Abhilasha and Gupta (2001) reported a lower prevalence for $E$. coli in a percentage ranged from 9.5 - 40.5\%. Regarding examined liver samples, 50 samples were tested and E. coli were positive in 40 with a percentage of $90 \%$. Nearly similar results were recorded by Ahmed (2011). Our were in disagree with (Abhilasha and Gupta, 2001, and Saha et al.,

Egypt. J. Vet. Sci. Vol. 44 (2013) 
2003) in which lower prevalence was detected. Moreover, 50 kidney samples collected from emergency slaughter broilers were investigated. Out of 50examined kidney samples, 30 were E. coli positive with a prevalence of $60 \%$ (Ahmed, 2011). However, (Sepehri and Zadeh, 2006) recorded higher occurrence of $E$. coli isolates from tested poultry kidney samples.

Concerning examination of small intestine of emergency slaughter broilers, 40 out of 50 samples were positive for $E$. coli with a prevalence of $80 \%$. Nearly similar findings werereported by Saha et al. (2003) and Ahmed (2011). Meanwhile, (Aphukan et al., 1990 and Abhilasha \& Gupta, 2001) reported lower occurrence in a percentage of $42.7 \%$. Finally, isolation of E. coli from cloacal swab of diseased broiler. Thirty out from 50 samples of cloacal swabs revealed E.coli isolation with prevalence of $60 \%$.

Using for serological tests and identification of randomly selected E. coli (20) isolates from different sources Table 2 clarified that, $E$. coli isolate was serotype O6(6), O111 (3), O55 (2), O114(2), O15(3),O125(2), and untyped (2). From the above mentioned data, it was clear that the most prevalent $E$. coli serotype isolates recovered from different sources of poultry broiler farms were O6 E. coli serotype, followed by O111, O15 then O114,O55, O125 and untyped. Nearly similar results were detected by Robab and Azadeh (2003) and Vandemaele, et al. (2003) investigated 100 APEC strains from 83 Belgian poultry farms, detecting only three serotypes O6 strains. Abd El-Salam (2004) serotyped the isolates of E.coli that recovered from broiler chickens. He found thatO114 (4), O55 (1), in addition to 32 untypable strains. Ibrahim (1998) showed that the predominant serotypesfrom 46 isolates of E.coli strains isolated from broiler chicken(2-6 weeks of age ) in the Suez Canal area, Egypt were O114:K-,O78:K-, O158:Kand O125:K70. Serotypes identified included O119:K69, O126:K71, O86:K61, O55:K60, O28:K67, O111:K58, O26:K60and O127:K63. Ibrahim et al. (1997) recovered one hundred and ninety E.coli isolates from broiler chickens 2-6 weeks of age with respiratory manifestation at Suez Canal area. They performed serotyping of 46 isolates and demonstrated that serotyped O114,O78, O158, O125, O119, O126, O86, O55, O111, O26 and O127 were predominant. A total of 162 strains belonged to EPEC serogroups 026, 044, 055, 086, O111, 0119, 0125, 0126, 0127, 0128, and 0142 (Ǿrskov and Ǿrskov, 1984).

Regarding the occurrence of Stx 1 gene in E. coli isolates. Our results revealed that out of $9 E$. coli isolates recovered from various broiler samples, one isolates (O6) were positive for Stxl gene yielded the expected size of $185 \mathrm{bp}$ PCR amplification. However, PCR results were negative for Stxl gene in other E. coli isolates. Nearly similar findings wererecorded by (Osek, 2003, Kaper et al., 2004, Badri et al. 2009 and Ahmed, 2011). 
Stx2 gene in isolated E. coli strains showed that out of $9 E$. coli isolates (O125), one were positive for the Stx 2 gene yielded a consistent fragment of $255 \mathrm{bp}$. While, PCR results were negative in other isolated E. coli isolates. These results substantiate what has been reported by (Kaper et al., 2004, and Leigh et al., 2005). Shiga toxigenic Escherichia coli (Stx1 and Stx 2) is an important cause of gastrointestinal disease in humans, particularly since these infections may result in life-threatening squeals such as the hemolytic-uremic syndrome (HUS) (Nataro and Kaper, 1998, Paton \& Paton1, 1998, Boerlin, et al., 1999 and Ojo et al., 2010).

The present study shows a significant decrease in $\mathrm{RBCs}$ count, $\mathrm{Hb}$ concentration and PCV in the affected birds indicate anemia of microcytichypochromic as showed by the erythrocytic indices that were proportionally correlated with the severityof infection of E. coli. These resultsare in accordance with Jain (1986) and Mona et al. (2012).

The increase in serum AST levels in this work could be due to liver damage produces by the infected bacteria. Campbell and Coles, (1986), mentioned that the increased of the activity of AST has been associated with hepatocellular damage in birds. Concerning ALT in chicken some studies reported elevation of ALT inbirds infected with bacteria (Campbell and Coles, 1986). Our result greed with Omaima (1987) and Mona et al., 2012) who observed a significant increase in (AST \& ALT, in chicken infected with E. coli. The significant change in total protein and albumin in the present work could be due to liver and kidney damage which could be associated with bacterial infection. Similar findings were previously mentioned by Riley et al. (1983) Pai et al. (1984), Campbell and Coles (1986) and Ostroff et al. (1989).The increase in uric acid and creatinine could be dueto the effect of the micro-organisms and its Toxin onthe kidneys. Our results is completely agree with Paiet al., (1984), Tzipori et al. (1987), Obrig et al. (1987) and Mona et al. (2012) who reported increased creatinine, urea level in case of renal disease. Hypocalcaemia, and hyperphosphatemia could be due to decrease calcium resorption by damaged renal tubules and associated with Hypoalbuminemia as reported by Campbell and Coles (1986) and Mark and Robert (1993). The decrease of potassium and sodium level inserum could be due to renal disease as reported byCampbell and Coles, (1986). Also the metabolism of calcium and phosphorus is closely linked in the body. Our result agreed with Ghanem (1986) and Campbell \& Coles (1986).

\section{Conclusion}

It could be concluded that the isolated bacterial pathogens play an important role in causing diseases in poultry and human consumer due to presence of toxin and losses in poultry farms at Ismailia and North Sinai. Our findings provide the information about the involvement of STEC in diarrhea in poultry in Ismailia and north Sinai. 


\section{References}

Abd El-Salam, W.M. (2004) Further studies on Escherichia coli strains isolated from broiler chickens. Ph.D. Thesis, (Bacteriology) Vet. Med. Cairo Univ., Egypt.

Abhilasha, S.P. and Gupta R.S. (2001) Pathogenicity and invitro drug resistance of Escherichia coli isolated from colibacillosis cases in chicks of Tarai Region. Ind. J. Comp. Micrbol. Immuno. Infect. Dis., 22 (2), 166-167.

Ahmed, D.A. (2011) Escherichia Coli Isolated From Broiler Farms with Special References to Virulence Genes of Isolated Strains. Master Veterinary Science Thesis, (Bacteriology) Vet. Med. Zagazig University.

Aphukan C., Ckalita C. and Duttag N. (1990) Isolation identification and serotyping of Escherichia coli from poultry. Indian J. Anim. Sci., 60 (5), 556-557.

Ayoub, M.A.M. (2007) Studies on epidemiology of Escherichia coli in some poultry farms. M.V.S. Thesis, Faculty of Vet. Med., Alexandria University.

Badri, S., Ingrid, F., Isabells, C., Mohammed, H., Aziz, F. and Nozha, C. (2009) Prevalence of virulence genes in Escherichia coli isolated from food in Casablanca (Microcco). Food Control, 20, 560-564.

Bansal, N.S. (1996) Development of a polymerase chain reaction assay for the detection of Listeria monocytogenes in foods. Letters of Applied Microbiology, 22, 353-6.

Barnes, J.H., Vaillancourt, J.P. and Gross, W.B. (2003) Colibacillosis. In: Diseases of Poultry, Y.M. Saif, H.J. Barnes, J.R. Glisson, A.M. Fadly, L.R. McDougald and D.E. Swayne (Ed.). Iowa State University Press, Ames, IA, pp. 631-652.

Beatty, M.E., Bopp, C.A., Wells, J.G., Greene, K.D., Puhr, N.D. and Mintz, E.D. (2004) Enterotoxin-producing Escherichia coli O169: H41， United States Emerg., Infect. Dis., 10, 518-521.

Boerlin, P., McEwen, S.A., Boerlin-Petzold, F., Wilson, J.B., Johnson, R.P. and Gyles, C.L. (1999) Associations between virulence factors of Shiga toxinproducing Escherichia coli and disease in humans. J. Clin. Microbiol., 37, 497-503.

Campbell, T. and Coles, E. (1986) Avian clinical Pathology, in "Veterinary Clinical Pathology ", $4^{\text {th }}$ ed., W.B Saunders Company. Philadelphia. London and Toronto.

Egypt. J. Vet. Sci. Vol. 44 (2013) 
Caraway, W.T. (1963) Uric acid. Stand Methods Clin. Chem. 4, 239-47.

Coles, E.H. (1986) "Veterinary Clinical Pathology", $4^{\text {th }}$ ed. W.B. Sounders Company, Philadelphia, London, Toronto, Mexico, Sydney, Tokyo, Hong Kong.

Dalton C.B., Mintz, E.D., Wells, J.G., Bopp, C.A. and Tauxe, R. (1999) Outbreak of enterotoxigenic Escherichia coli infection in American adults: a clinical and epidemiologic profile. Epidemiol. Infect., 123, 9-19.

Dziva, F. (2010) Deciphering the infection biology of avian pathogenic Escherichia coli: role of experimental infection models. Technology and education topics in applied microbiology and microbial biotechnology.

Doumas, B. and Biggs, H. (1972) "Standard Methods of Clinical Chemistry", vol.7, Academic Press New York.

Ewers, C., Janssen, T., Kiessling, S., Philip, H.C. and Wieler, L.H. (2005) Rapid detection of virulence associated genes in avian pathogenic Escherichia coli bymultiplex polymerase chain reaction. Avian Dis., 49, 269-273.

Fantasia, M., Ricci, N., Manupella, A., Martinil, A., Filetici, E. and Lurelli, T. (1990) Phage type and DNA plasmid of Salmonella typhimurium isolates in the area of Isernia, Italy. Epidemiol. Infect., 109(3),167-323.

Ghanem, I.A. (1986) Epidemiological studies on pasteurellosis in dukes: duks. Ph.D Thesis, Dept. of poultry and fish diseases, Dept. of poultry and fish Diseases. Fac. of Vet. Med., Zagazig Univ.

Goodwin, J.F. (1970) Determination of serum phosphorus. Clin. Chem., 6 (9), 776-780.

Greenwood, D., Slack, R.C.B. and Peutherer, J.F. (2002) "Medical Microbiology", $16^{\text {th }}$ ed., Churchill Livingstone, Edinburgh-London-New York-Philadelphia-St. LouisSydney-Toronto, ISBN: 0-443-07077-6, pp. 168-173.

Henry, R.J. (1979) Colorimetric methods for determination of serum creatinine. Clinical Chemistry, Principles and techniques, $2^{\text {nd }}$ ed. Harper and Row, 525 p.

Ibrahim, F.A. (1998) Studies on ground water and possible healthrisks in south Sinai, Egypt. SCVMI, 1(1), 141-150.

Ibrahim, A.I., El-Attar, A.A. and El-Shahidy, M.S. (1997) Studies on E.coliisolates from respiratory affected broilers and protection evaluation of different prepared bacterines. Assiut Vet. Med. J., 37(74), 152-162.

Jain, N.C. (1986) "Schalm's Veterinary Hematology", $4^{\text {th }}$ ed., Lea and Febiger, Philadelphia.

Jain, N.C. (2000) "Schalm's Veterinary Hematology", $8^{\text {th }}$ ed. Lea and Febiger, Philadelphia, U.S.A.

Egypt. J. Vet. Sci. Vol. 44 (2013) 
Jordan, F.T., Williams, N.J., Wattret, A. and Jones, T. (2005) Observations on salpingitis, peritonitis and salpingoperitonitis in a layer breeder flock. Vet. Rec., 157, 573-577.

Kaper, J.B., Nataro, J.P. and Mobley, H.L.T. (2004) Pathogenic Escherichia coli. Nature Reviews Microbiology, 2, 123-140.

Leigh, W, Topp, E., Schraft, H. and Leung, K.T. (2005) Multiplex PCR-DNA probe assay for the detection of pathogenic Escherichia coli. Journal of Microbiological Methods, 60, 93-105.

Mark, S. and Robert, T. (1993) E. coli O157:H7 ranks as the fourth most costly foodborne disease. Food Review USDA/ERS, 16, 51-59.

McClure, P.G. (2000) Microbiological hazard identification in the meat industry. HATCP in the meat industry.CRC PRESS wood head publishing limited, Cambridge. 2000, 157-176.

Mona S. Zaki, Olfat Fawzy and Osfor, M.H. (2012) Effect of E. coli O:157 on Baladi Broiler Chicken and some Biochemical studies. Life Science Journal, 9 (1), 91-94.

Nataro, J.P. and Kaper, J.B. (1998) Diarrheagenic Escherichia coli. Clin. Microbiol. Rev., 11, 142-201.

Natt, M.P. and Herrick, A.C. (1952) A new blood diluent for counting the erythrocytes and leucocytes of chickens. Poul. Sci. 31, 735-738.

Obrig, T., Del Vecchio, P., Karmali, M., Petric, M., Moran, T. and Judge, T. (1987) Pathogenesis of hemolyticuremic syndrome (Letter). Lancet., 2, 687-689.

Ojo, O.E., Ajuwape, A.T., Otesile, E.B., Owoade, A.A., Oyekunle, M.A. and Adetosoye, A.I. (2010) Potentially zoonotic shiga toxin-producing Escherichia coli serogroups in the faeces and meat of food-producing animals in Ibadan, Nigeria. Int. J. Food Microbiol., 15, 142 (1-2), 214-221.

Omaima, A.R. (1987) Liver function tests in relation to some bacterial and viral diseases in chickens. Master Veterinary Science of Biochemistry- Faculty of Vet. Med., Zagazig University (Benha branch).

Ostroff, S., Kobayashi, J. and Lewis, J. (1989) Infections with Escherichia coli 0157:H7 an emerging gastrrointestinal pathogen. Results of a one-year, prospective, populationbased study. JAMA., 262, 355-359. 
Ǿrskov, F. and Ǿrskov, I. (1984) Serotyping of Escherichia coli. In: Methods in Microbiology, Bergan, T. (Ed.), Academic Press, New York, 14, 43-112

Osek, J. (2003) Development of a multiplex PCR approach for the identification of shiga toxin-producing Escherichia coli strains and their major virulence factor genes. Journal of Applied Microbiology, 95, 1217-1225.

Pai C., Gordon R., Sims, H. and Bryan, L. (1984) Sporadic cases of hemorrhagic colitis associated with Escherichia coli 0157:H7. Clinical. Epidemiologic and bacteriologic features. Ann. Intern. Med., 101, 738-742.

Paton, A.W. and Paton, J.C. (1998) Detection and characterization of shiga1.toxigenic Escherichia coli by using multiplex PCR assays for $s t x 1$, st $x 2$, eaeA, enterohaemorrhagic E.colihlyA, rfbO111 and rfbO157. J. Clin. Microbiol., 36, 598-602.

Paton, J.C. and Paton, A.W. (1998) Pathogenesis and diagnosis of Shiga toxinproducingEscherichia coli infections. Clin. Microbiol. Rev., 11, 450 - 479.

Quinn, P., Carter, M., Markey, B. and Carter, G. (1994) "Clinical Veterinary Microbiology", $5^{\text {th }}$ ed., Year Book Europe Limited, Spain. p250.

Reitman, S. and Frankel, S. (1957) A colorimetric method for determination of AST and ALT. Am. J. Clin. Path., 25, 56- 60 .

Riley L., Remis R., Helgerson S., McGee H., Wells J. and Davis, B. (1983) Hemorrhagic colitis associated with a rare Escherichia coli serotype. N. Engl. J. Med., 2, 132-135.

Robab, R.T. and Azadeh, N. (2003) Isolation, Identification and Antimicrobial Resistance Patterns of E.coliisolatedfrom Chicken flocks. Iranian J. Pharm. Therapeutics, 2, 39-42.

Rosario, C.C., Lopez, A.C., Tellez, I.G., Navarro, O.A., Anderson, R.C. and Eslava, C.C. (2004) Serotyping and virulence genes detection in Escherichia coli isolated from fertile and infertile egg, dead in shellembryos and chickens with yolk sac infection. Avian Dis., 48 (4), 791-802.

Saha, A., Hui, A.K, Das, R., Roy, J.P., Ray, N. and Mahata, T.K (2003) Occurrence of Escherichia coli from broiler birds in West Bengal and their antibiogram. India. J. Anim. Health., 42 (2), 136-141.

Saif, Y.M., Barnes, H.J., Glisson, J.R., Fadly, A.M., McDougald, L.R. and Swayne, D.E. (2003) Disease of Poultry. 11th Edn., Iowa State Press, Iowa.

Salyers, A.A., and Whitt, D.D. (2002) Diarrheagenic Escherichia coli strains In: Bacterial Pathogenesis A Molecular Approach, $2^{\text {nd }}$ ed. American Society of Microbiology, Washington. pp. 407-421.

Sarkar, B. and Chanhan, U. (1967) Determination of serum calcium. Anal. Biochem., 50, $155-158$

Egypt. J. Vet. Sci. Vol. 44 (2013) 
Sepehri, G. and Zadeh, A.H. (2006) Prevalence of bacterialresistance to commonly used antimicrobials among Escherichia coli isolated from chickens in kerman province of Iran. J. Med. Sci. Pakistan., 6 (1), 99-102

Sharada, R., Krishnappa, G. and Upendra, H.A. (2001) Serological 'O' grouping and drug susceptibility of E.colistrains from chickens. Indian Veterinary Journal., 78 (1), 78-79.

Snedecor, G. and Cochran, W. (1982) "Statistical Methods", $6^{\text {th }}$ ed., Iowa state Univ., Press. Ames. Iowa, U.S.A.

Thangapandian, E., Vijayarani, K., Ramadass, P. and Nainar, A.M. (2006). Distribution of virulence associated genes in avian pathogenic Escherichia coli isolates from Tamil Nadu. Indian J. An. Sci., 76, 284-287.

Tzipori, S., Wachsmuth, I., Chapman, C., Birden, R., Brittingham, J. and Jackson, C. (1987) The pathogenesis of hemorrhagic colitis caused byEscherichia coli $0157: \mathrm{H} 7$ in gnotobiotic piglets. J. Infect. Dis., 154, 712-716.

Van Kempen, E.J. and Zijlstra, W.G. (1961) Standarization of hemoglobinometry II.The hemoglobincyanide method. Clin. Chim. Acta., 6, 538-544.

Vandemaele, F.J., Mugasa, J.P., Vandekerchove, D. and Goddeeris, B.M. (2003) Predominance of the pap GII allele with high sequence homology to that of human isolates among avian pathogenic Escherichia coli (APEC)," Veterinary Microbiology 97 (3-4), 245-257,

Vanderkerchove, D., de Herdt, P., Laevens, H. and Pasmans, F. (2004) Risk factors associated with colibacillosis outbreaks in caged layer flock. Avain Pathol., 33, 337 342 .

Zanella, A., Alborali, G.L., Bardotti, M., Candotti, P., Guadagnini, P.F., Martino, P.A. and Stonfer, M. (2000) Severe Escherichia coli O111 septicemia and polyserositis in hens at the start of lay. Avian Pathol., 29 (4), 311-317.

(Received 22/12/2013;

accepted $10 / 9 / 2015$ 


\title{
التميز بين سلالات الايشريشيا كولاى المسبية للإسهال في بداري التسمين باستخدام PCR المتعدد الأثرات
}

\author{
منى عبداللاه احمد ، فاطمة محمد احمد يوسف و أحمد جمال عبد الرحمن

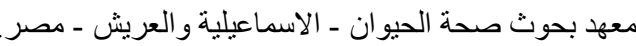

\begin{abstract}
في محاولة للتحقيق من تفشي الإسهال الحاد في الطيور الدواجن في الإسماعيلية،

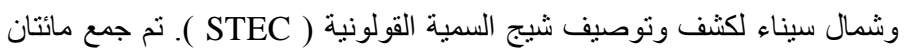

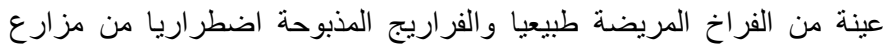

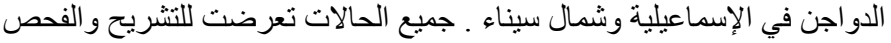

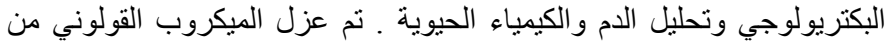

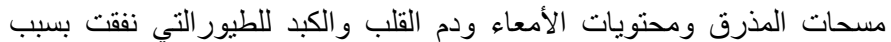

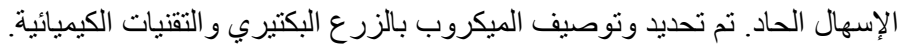

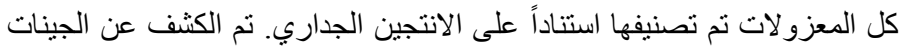

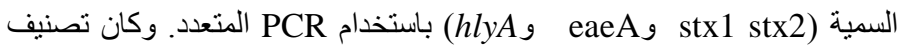

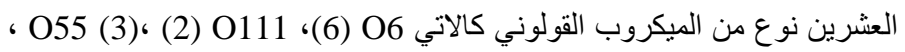

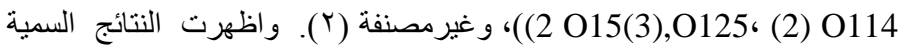

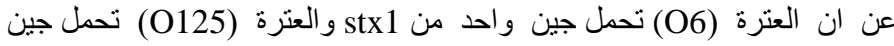
واحد من stx2 والباقي من العثرات لا يحمل أي سميات. واظهرت التحاليل

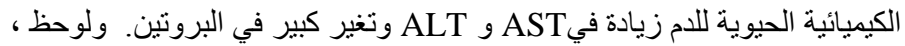

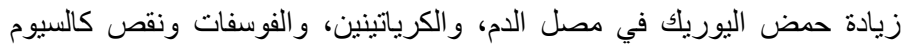

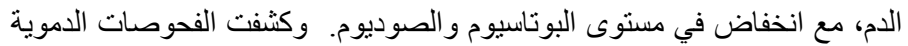

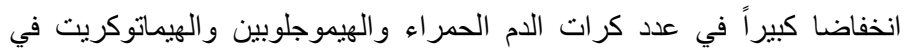

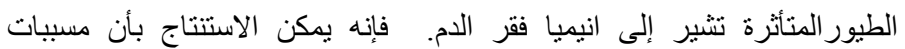

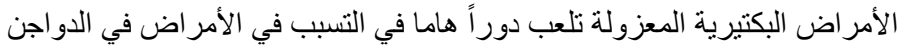

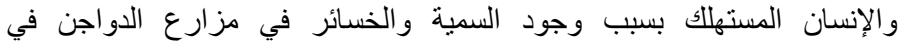
الإسماعيلية وشمال سيناء.
\end{abstract}

